\title{
Circulating Levels of Progesterone as Biochemical Evidence of Ovulation is Method Dependent
}

\author{
IBRAHIM A. HASHIM, PhD, FACB ${ }^{1}$, and TARIF H. ZAWAWI, FRCPI, FACB ${ }^{2}$ \\ Department of Pathology and Laboratory Medicine ${ }^{1}$, King Khalid National Guard Hos- \\ pital, and Department of Medicine ${ }^{2}$, Faculty of Medicine and Allied Sciences, \\ King Abdulaziz University, Jeddah, Saudi Arabia
}

\begin{abstract}
Serum progesterone level is used as an indictor of ovulation and several assays are commercially available for its routine measurement. Target values suggestive of ovulation, deficient luteal phase and anovulation have been proposed and are widely sighted in the literature. In this study, we compared the use of two different assays namely: Amerlite (Johnson \& Johnson, United Kingdom), and AxSym (Abbott Diagnostics, Germany) for measurement of serum progesterone. In patients being investigated for infertility $(\mathrm{n}=$ 93), serum progesterone levels showed good correlation $(r=0.92)$ between the two methods; however, values were significantly different $(\mathrm{P}<0.005)$. Using published cut-offs levels for progesterone, $28.3 \%, 60.8 \%$, and $10.9 \%$ of patients had ovulatory, anovulatory, ad deficient luteal phase, respectively, as measured by the Amerlite assay, compared to $32.6 \%, 60.8 \%$, and $6.5 \%$ when using the AxSym assay. Thus when using the AxSym assay, higher percentage of patients would be classified as having ovulaory cycle. This study indicated that methodological differences on their own right play a significant role in the determination of ovulatory statue of patients. The study showed that laboratory-based target values need to be established.
\end{abstract}

Keywords: Progesterone, Ovulation

\section{Introduction}

Circulating progesterone level is used as an indicator of either natural or induced ovula-

\footnotetext{
Correspondence \& reprint requests to: Prof. Tarif H. Zawawi, Department of Medicine, King Abdulaiz University, P. O. Box 80215, Jeddah 21589, Saudi Arabia

Accepted for publication: 04 August 2002. Received: 04 May 2002.
} 
tion and several assays are commercially available for its measurement. Disorders of ovulation including anovulation are common and account for $15-20 \%$ of patients where progesterone levels are usually low. Target values suggestive of ovulation, deficient luteal phase, and anovulation have also been proposed and are widely sighted in the literature.

Serial ultrasound monitoring and direct observation of ovulation at laparoscopy are used to indicate ovulation with the latter being used only in selected patients whereas ultrasound's use being time consuming. Although basal body temperatures are used to predict ovulation, it is not reliable.

Serum progesterone measurement is used in fertility studies to assess corpus luteum function, to evaluate placental function during pregnancy, and as an aid in confirming ovulation, it is in the latter that its measurement is widely employed ${ }^{[1]}$.

A number of assays are commercially available and it has been reported ${ }^{[2]}$ that serum progesterone levels greater than $30 \mathrm{nmol} / \mathrm{L}$, between 30 and $18 \mathrm{nmol} / \mathrm{L}$ and less than 18 $\mathrm{nmol} / \mathrm{L}$ were consistent with ovulation, deficient luteal phase, and anovulation, respectively. However, different workers have chosen very different target values to indicate ovulation, varying from 3.2 to $30.0 \mathrm{nmol} / \mathrm{L}$. A large emphasis has been placed on the clinical criteria used in collection time and little was attributed to the now improved progesterone immunoassays as a cause of such wide discrepancies.

This study compared the use of two different progesterone assays in the investigation of ovulation and examined if methodological differences could on their own contribute to discrepancies in patients' classification.

\section{Materials and Methods}

Subjects: Patients $(n=93)$ being investigated for infertility were entered into the study. Patients age ranged from 18 to 40 years old (median $=26$ years old). Blood samples were collected on the 21 st day of the menstrual cycle following hospital ethical and research committee approval.

Biochemical Measurements: Serum was separated and stored at $-20^{\circ} \mathrm{C}$ until analysis. Progesterone levels were determined using two different immunoassays: namely; Amerlite immunoassay (Johnson and Johnson, Clinical Diagnostics, Amerham, U.K.) and AxSym immunoassay analyser (Abbott Diagnostics, Germany). Analysis was performed according to the manufacturers' instructions. Statistical analysis was performed using computer software. Inter- and inter assay imprecision were determined for both assays at three different serum progesterone levels. Linearity studies were performed by serially diluting six samples with $0 \mathrm{nmol} / \mathrm{L}$ standard of the Amerlite assay and with the AxSym assay-diluent and assaying for progesterone levels using both assays, respectively. 


\section{Results}

Serum progesterone levels ranged from 0.2 to $76.6 \mathrm{nmol} / \mathrm{L}$ (median 3.9) in the Amerlte assay compared to 0.3 to $103.4 \mathrm{nmol} / \mathrm{L}$ (median 4.5) in the AxSym assay. There was good correlation between both assays $(r=0.92)$ (Fig. 1). However, the data was not normally distributed and Wilcoxon's non-parametric test showed significant difference between results obtained by the two methods $(\mathrm{P}<0.005)$. Higher values were observed in the AxSym assay (Fig. 2).

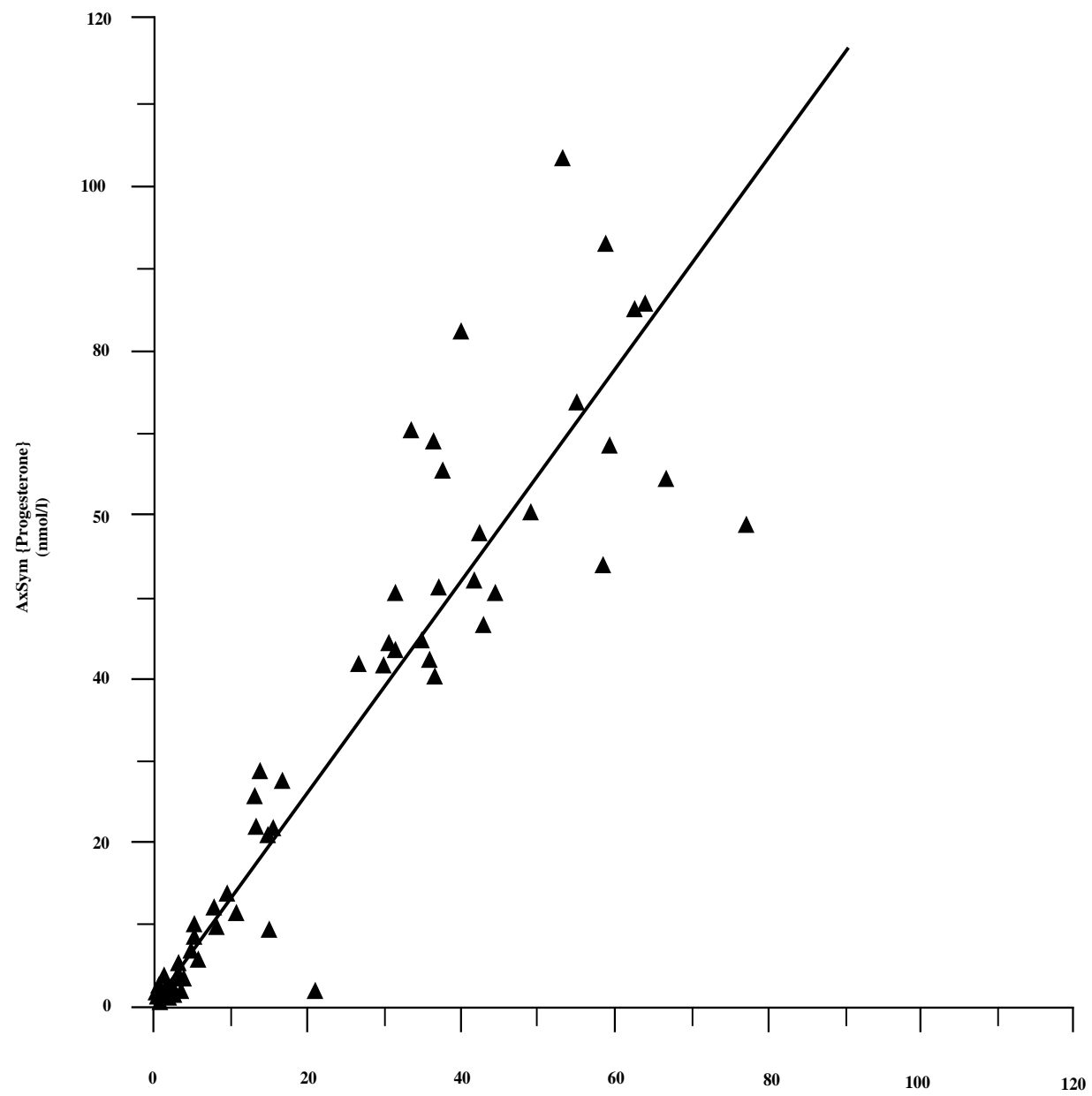

Fig. 1 Correlation between serum progesterone results obtained by Amerlite and AxSym immunoassays. 


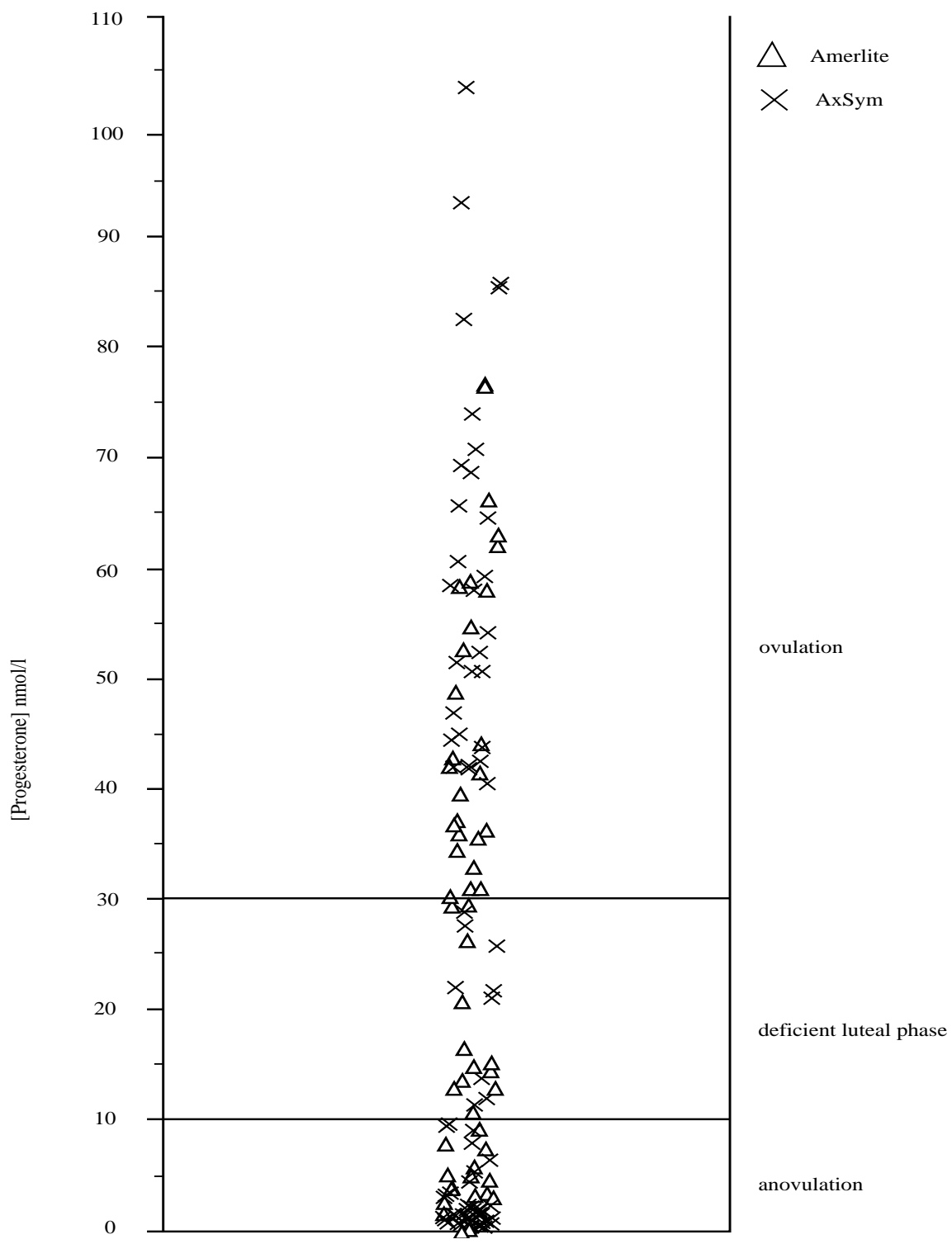

Fig. 2 Patients with ovulation, anovulation and deficient luteal phase as indicated by serum progesterone concentration measured using the two immunoassays. 
Using the above progesterone "cut-off" levels ${ }^{[1]} .28 .3 \%, 60.8 \%$, and $10.9 \%$ of patients had ovulatory, anovulatory cycles, and efficient luteal phase, respectively, as measured by Amerlite assay as compared to 32.6\%, 60.8\%, and 6.5\% when using the AxSym assay, respectively.

Inter-assay imprecision ranged from $25.0 \%, 5.0 \%$, and $8.5 \%$ at $1.1,15.8$, and 65.0 $\mathrm{nmol} / \mathrm{L}$, respectively, in the Amerlite assay as compared to 9.2, 6.1, and 5.9 at 3.2, 17.5, and $69.9 \mathrm{nmol} / \mathrm{L}$, respectively, in the AxSym assay.

Linearity studies were performed and showed good recovery and parallel responses (data not shown).

\section{Discussion}

This study compared the use of two different immunoassays for serum progesterone measurement. Assays were based on competitive binding between serum progesterone and assay progesterone. In the Amerlite assay, horseradish peroxidase-conjugated progesterone competes with serum progesterone for anti-progesterone antibody, the latter is captured by a second antibody coated onto a 96 well-plate, whereas, in th AxSym assay, immobilized progesterone competes with serum progesterone for anti-progesterone antibody labeled with alkaline phosphates. The final signal in both assays is inversely proportional to the concentration of serum progesterone.

The Amerlite assay had been calibrated against a pure progesterone preparation and values were checked to relative to Gas-chromatography-Mass Spectrometer (GCMS) calibrated samples. The standard used is different from that in the Abbott assay; however, it was said to have good correlation with GCMS results ( $r=0.994$, Abbott Diagnostics, personal communication). The Amerlite immunoassay showed poor precision at low progesterone levels $(<15 \mathrm{nmol} / \mathrm{L})$, whereas, both immunoassays showed good precision at higher progesterone levels.

Although results obtained by both assays showed good correlation, results were significantly different. It is possible that the nature of both assays and the presence of competitors / inhibitors in serum may contribute to the discrepancy. Reported cross reactivity studies by both manufacturers were comparable.

Patients classified as having anovulatory cycles were the same by both assays; however, more patients had higher progesterone results by AxSym immunoassay and thus were classified as having ovulatory cycles.

The study highlighted that, in addition to the published discrepancy in serum progesterone "cut-off" limits, methodological differences play a significant role and that further studies are required to investigate such discrepancy. Laboratory based progesterone target values should, therefore, be established. 


\section{References}

[1] Abraham GE, Maroulis GB, Marshall JR. Evaluation of ovulation and corpus luteum function using measurements of plasma progesterone. Obstet Gynecol 1974; 44(4): 522-525.

[2] Beastall GH. Role of endocrine biochemistry laboratories in the investigation of infertility. J Clin Pathol 1993; 46(9): 790-794.

[3] Abdulla U, Diver MJ, Hipkin LJ, Davis JC. Plasma progesterone levels as an index of ovulation. $\mathrm{Br}$ J Obstet Gynaecol 1983; 90(6): 543-548.

[4] Hull MGR, Savage PE, Bromham DR, Ismail AAA, Morris AF. The value of a single serum progesterone measurement in the midluteal phase as a criterion of a potentially fertile cycle ('ovulation') derived form treated and untreated conception cycles. Fertil Steril 1982; 37(3): 355-360.

[5] Petsos P, Chandler C, Oak M, Ratcliffe WA, Wood R, Anderson DC. The assessment of ovulation by a combination of ultrasound and detailed serial hormone profiles in 35 women with long-standing unexplained infertility. Clin Endocrinol 1985; 22(6): 739-751. 


\title{
دراسة لمستوى هرمون البروجسترون في مصل الدم واستخدام القيم كمؤشر لحدوث التبويض
}

\author{
إبر اهيم هاشم و طريف هشام زواوي

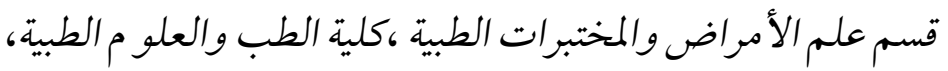 \\ جامعة الملك عبد العزيز

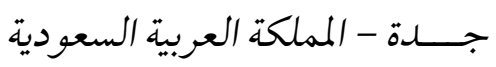

المستخلص. هناك عدة و سائل تحليلية متوفرة تجاريا وتستخدم روتينيا

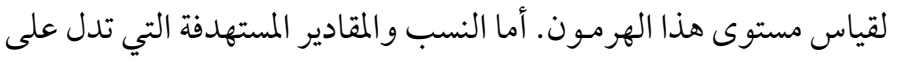

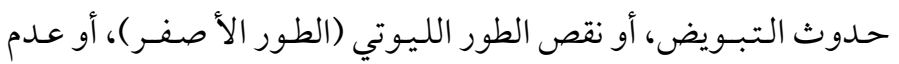

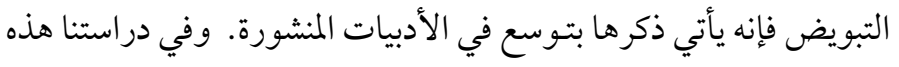

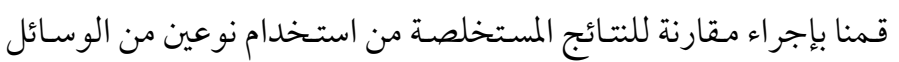

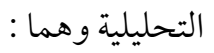
1 - أمر لايت (جونسون آند جونسون) - المملكة المتحدة

1. Amerlite (Johnson \& Johson)

2. AxSym (Abbott Diagnestics) أكسيم (أبوت دياجنيستك) - ألمانيا ولقد تم قياس مستوى البروجسترون لثلاث وتسعين مريضة يشتكين

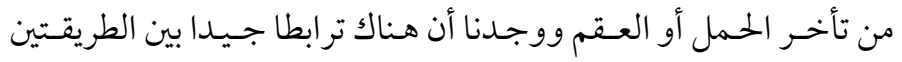

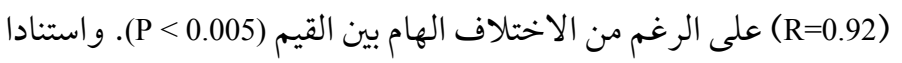

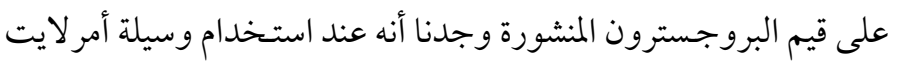

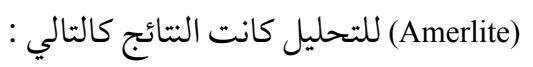

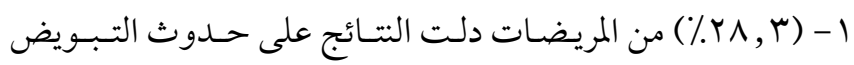
لديهن.

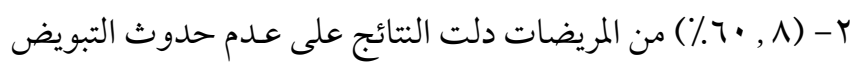




$$
\begin{aligned}
& \text { r- (9 , • (\%) من المريضـات دلت النتـائج على قـصـور في الطور } \\
& \text { الليوتي (الطور الأصفر - Luteal phase) لديهن. } \\
& \text { أمـا في حالة استـخدام وسيلة أكسيم (AxSym) فقـد كانـت النتائج } \\
& \text { كالتالي: }
\end{aligned}
$$

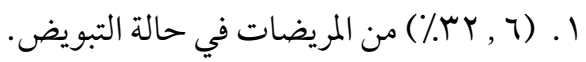

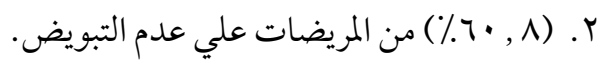

$$
\begin{aligned}
& \text { r. (0, 7\%٪) من المريضات لديهن قصور في الطور الليوتي. }
\end{aligned}
$$

ومن ذلك نخلص أنه باستخدام وسيلة أكسيم نحصل على نسبة أعلى

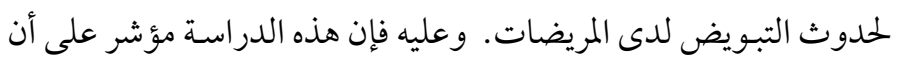
اختلاف الطرق المستخـدمـة في الفحوصات يلعب دورا كبيرا في تحديد

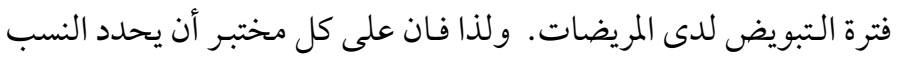
و القيم المستهدفة الخاصة به. 